\title{
Vaihtoehtona osa-aikainen laiduntaminen
}

\author{
Auvo Sairanen ${ }^{1)}$, Jenni Hakosalo ${ }^{2)}$, Hannele Khalili ${ }^{3)}$ ja Perttu Virkajärvi ${ }^{1)}$ \\ 1) MTT Pohjois-Savon tutkimusasema Halolantie 31 A 71850 Maaninka, etunimi.sukunimi@mtt.fi \\ ${ }^{2)}$ MTT Pohjois-Savon tutkimusasema Halolantie 31 A 71850 Maaninka, hakosalo@hytti.uku.fi \\ 3) MTT Eläinravitsemus 31600 Jokioinen, hannele.khalil@mtt.fii
}

\section{Tiivistelmä}

Karjakoon kasvaminen ja Suomen vaihtelevat nurmenkasvuolosuhteet ovat vähentäneet laiduntamisen suosiota lehmien kesäruokintamuotona. Karjakoon kasvu lisää laidunalan tarvetta navetan läheisyydessä ja vaihtelu nurmen kasvunopeudessa vaatii kesän eri aikoina muuttuvan pinta-alan ympärivuorokautiseen laitumeen perustuvassa kierrossa. Osa-aikainen laidun tuo helpotusta näihin ongelmiin. Lisäsäilörehun avulla laidunalaa ei tarvitse nostaa eläinmäärän mukaisesti ja vaihtelevan nurmenkasvun vaatima jousto myös löytyy syötetyn säilörehun määrästä.

Osa-aikalaiduntamisen vaikutusta maidontuotantoon ja lehmien hyvinvointiin selvitettiin kahtena kesänä MTT Pohjois-Savon tutkimusasemalla. Vuonna 2003 laiduntaminen toteutettiin yölaitumena ja vuonna 2005 päivälaitumena. Vertailuryhmänä oli molempina vuosina sisäruokinta yhdistettynä kahden tunnin tarhaulkoilutukseen. Käytetty säilörehu oli ensimmäisen korjuukerran nurmisäilörehua. Väkirehumäärä oli koko ajan vakio, $9 \mathrm{~kg} / \mathrm{vrk}$. Rehun raakavalkuaispitoisuus oli ensimmäisenä vuonna $167 \mathrm{~g} / \mathrm{kgka}$. Toisena koevuonna väkirehu sisälsi kaksi eri raakavalkuaistasoa: $130 \mathrm{~g} / \mathrm{kgka}$ ja 176 g/kgka.

Yölaidunryhmä (vuosi 2003) tuotti kesän aikana keskimäärin 3,9 kiloa enemmän maitoa kuin koko ajan säilörehulla ruokittu ryhmä. Eroa selittää laidunryhmän korkeampi kuiva-ainesyönti ja lisääntynyt dieetin karkearehuosuuden energiaväkevyys laitumen korvatessa säilörehua. Päiväaikaan laidunnetun ryhmän (vuosi 2005) tuotokset olivat alkukesällä samansuuruiset kontrolliin verrattuna mutta laidunryhmän tuotos oli heinä- ja elokuussa noin $2 \mathrm{~kg}$ sisäryhmää suurempi. Nurmen kasvurytmi oli alkukesällä 2005 hyvin nopea ja laidunnurmi pääsi korsiintumaan. Tämä alensi laitumen rehuarvon säilörehun tasolle mikä selittää alkukesällä erojen puuttumisen ryhmien välillä. Loppukesällä laidunnurmennurmen laatu parantui. Koko laidunkauden keskimääräinen vertailuryhmien välinen ero maitotuotoksissa oli $1.5 \mathrm{~kg} / \mathrm{pv}$.

Yölaitumen merkittävimpänä erona päivälaitumeen verrattuna oli 6 tuntia pidempi laidunaika ja samalla korkeampi odotettavissa oleva maitotuotos dieetin karkearehuosuuden sulavuuden nousun vuoksi. Peltoalan tarve tietysti lisääntyy laidunajan suhteessa. Molemmissa laidunvaihtoehdoissa läpi kesän tarkasteltuna tuotokset pysyivät melko vakiona huolimatta kesän 2003 hellekaudesta ja kesän 2005 vaihtelevasta laidunrehun laadusta. Viileys on kiistaton etu yölaiduntajille, vaikka tämä ei välttämättä maitotuotoksissa näkyisikään. Laiduntamisen etua lehmien hyvinvoinnille ei tutkimuksessa pystytty todistamaan. Täytyy kuitenkin pitää mielessä, että laidun on ainoa tapa suoda lehmille lajityypillinen käyttäytyminen kesäaikaan.

Kesän 2005 vertailussa ohran korvaaminen rypsillä tuotti säilörehuruokituilla lehmillä aikaisempiin kokeisiin verrattuna tyypillisen $0,9 \mathrm{~kg}$ maitoa / kilo rypsiä. Laidunryhmän rypsivaste oli vain $0,5 \mathrm{~kg}$ maitoa / kilo rypsiä. Osa-aikalaitumen heikompi rypsivaste on johdonmukainen kesällä 2004 MTT:1lä tehdyn laidunruokintakokeen kanssa, jossa lisävalkuaisella ei saatu juuri ollenkaan lisätuotosta ympärivuorokautisesti laidunnetuilla lehmillä. Koti- ja ulkomailla tehdyissä laidunkokeissa lisävalkuaisvasteet ovat olleet vaihtelevia, mutta tämän koesarjan perusteella laidunkauden kannattava lisävalkuaistaso on sisäruokintaa pienempi.

Asiasanat: maidontuotanto, laidun, osa-aikalaidun, valkuaisruokinta 


\section{Johdanto}

Rakennemuutoksesta johtuva karjakoon kasvaminen ja Suomen vaihtelevat nurmenkasvuolosuhteet ovat vähentäneet laiduntamisen suosiota lehmien kesäruokintamuotona. Karjakoon kasvu lisää laidunalan tarvetta navetan läheisyydessä ja vaihtelu nurmen kasvunopeudessa vaatii kesän eri aikoina muuttuvan laidunalan ympärivuorokautiseen laitumeen perustuvassa kierrossa. Laiduntaminen on kuitenkin perinteinen kesäruokintamuoto, joka mahdollistaa lehmien lajityypillisen käyttäytymisen. Talouslaskelmien perusteella laidun on osoittautunut edullisimmaksi lypsylehmien rehuksi. Laidun on myös luontevin vaihtoehto toteuttaa vuonna 2006 voimaantuleva lypsylehmien jaloitteluvelvollisuus. Näiden tekijöiden hyödyntäminen edellyttää tutkimukselta ja neuvonnalta uusia ohjeita, jotta laidun pysyisi mukana lehmien rehuvalikoimassa myös tulevina vuosina.

Osa-aikalaidun on käytännössä osoittautunut Suomen olosuhteisiin sopivimmaksi laidunmuodoksi. Lisäsäilörehun avulla laidunalaa ei tarvitse lisätä eläinmäärän kasvaessa ja sääolosuhteiden mukaan vaihtelevan nurmenkasvun vaatima jousto myös löytyy syötetyn säilörehun määrästä. Laidunalaa ei helposti lisätä kuivan tai kylmän kauden vähentäessä nurmen kasvua, mutta säilörehua voidaan aina punnita varastotilanteen sallima tarvittava määrä. Nurmen kannalta otollisten säiden vallitessa hyvä nurmenkasvu taas saadaan hyödynnettyä sisäruokinta-aikaa rajoittamalla. MTT:1lä kaksivuotisena (2003 ja 2005) toteutettu osa-aikalaiduntutkimus tuo uutta tietoa laiduntamisen merkityksestä lehmien hyvinvointiin ja maitotuotokseen. Toisena koevuotena tarkastelukohteena oli myös lehmien lisävalkuaistarve laitumella, mistä on saatavilla tietoa vain rajoitetusti.

\section{Aineisto ja menetelmät}

Yölaidunkokeen (kesä 2003) järjestelyt ja hyvinvoinnin arviointiin keskittyneet tulokset on julkaisu aikaisemmin Maataloustieteen päivillä (Sairanen ym. 2004). Vuonna 2005 suoritetussa kokeessa vertailtavina käsittelyinä olivat jatkuva sisäruokinta säilörehulla ja osa-aikainen laidun päivälaitumena. Pääasiallinen ero näiden kahden vuoden välillä oli laidunaika, joka yölaidunvertailussa oli 12 tuntia ja päivälaidunvertailussa 6 tuntia. Hyvinvointitutkimus keskittyi ensimmäiseen koevuoteen, mutta lehmien käyttäytymisseuranta oli mukana myös jälkimmäisenä koevuotena.

Kesällä 2005 koe toteutettiin 2x2 faktoriaalisen cross-over koeasetelman mukaisesti. Koejäseninä oli ruokintastrategia (osa-aikalaidun ja kokoaikainen säilörehuruokinta) sekä väkirehun valkuaistaso (RV 13,0 \% ja RV 17,6 \% / kgka). Lehmät jaettiin neljän lehmän blokkeihin poikima-ajan, siemennyspäivän, poikimakerran ja koetta edeltäneen maitotuotoksen mukaan. Käsittelyt arvottiin lehmille kunkin blokin sisällä. Lehmät pysyivät koko ajan joko säilörehu- tai laidunryhmässä, mutta vaihtoivat valkuaistasoa kahden viikon välein. Yhteensä näitä koejaksoja oli 6, kaksi jaksoa jokaista laidunkuukautta kohti. Kolmen jakson aikana läpi käydyt käsittelysequenssit valkuaisfaktorin suhteen oli valittu blokeittain siten, että kaikki dieettijärjestysvaihtoehdot tulivat käydyiksi läpi. Käsittelysequenssit toistettiin kahdesti kesän aikana. Jokaisen koejaksojen 10 ensimmäistä päivää olivat siirtojaksoa ja 5 viimeisen päivän keskiarvoa käytettiin tulosten käsittelyyn.

Päivälaidunryhmän laidunkausi alkoi siirtoruokinnalla 23.5 ja päättyi 30.8. Lehmät laidunsivat kiertävällä lohkosyötöllä siten, että arvioitu päivittäin tarjolla olleen laitumen määrä ylitti $25 \mathrm{~kg}$ ka/lehmä. Päivittäin samalla lohkolla vietetty aika ei ylittänyt 3 päivää. Laitumella lehmät saivat vettä vapaasti painevedellä toimivista vesikupeista. Vapaasti tarjolla ollut säilörehu oli ensimmäisen sadon timotei-nurminata rehua (taulukko 1). Viljaryhmän väkirehu oli ohra-kauraa $(4,5 \mathrm{~kg}+4,5 \mathrm{~kg} / \mathrm{pv}) \mathrm{ja}$ valkuaisryhmän väkirehu oli ohra-kaura-rypsi seosta $(3,5 \mathrm{~kg}+3,5 \mathrm{~kg}+2 \mathrm{~kg} / \mathrm{pv})$. Väkirehut jaettiin lehmille kolmena annoksena; aamulla ennen lypsyä klo 6.00, laitumelta tulon yhteydessä klo $15.00 \mathrm{ja}$ lypsyn jälkeen 17.30.

Lehmiltä mitattiin päivittäin maitotuotos sekä säilö- ja väkirehun kulutukset. Maidon pitoisuudet määritettiin jokaisen keruujakson lopussa kahtena peräkkäisenä päivänä aamu- ja iltalypsyt erikseen. Käyttäytymisseurannassa (suora seuranta ulkona ja videointi sisällä) oli mukana pääkäyttäytyminen, aggressiot ja turkinhoito. Käyttäytymisdatan purku on vielä kesken eikä raportoida tässä yhteydessä.

Tulokset analysoitiin SAS Mixed proseduurilla käyttäen mallia:

$\mathrm{y}=$ blokki + laidun + valkuaistaso + jakso + laidun*valkuaistaso + jakso*laidun + lehmä 
Lehmä oli mallissa satunnaismuuttujana (random) ja loput kiinteinä tekijöinä (fixed). Blokkitekijän mukanaolo on perusteltua laidunfaktorin vuoksi, koska lehmät pysyivät koko ajan joko laidun- tai sisäruokintaryhmässä. Tilastollisessa tarkastelussa oli mukana myös blokki*valkuaistaso ja blokki*laidun -yhdysvaikutukset, mutta tilastollisesti merkityksettömänä ne jätettiin pois.

\section{Tulokset ja tulosten tarkastelu}

Kesä 2003 oli sääolosuhteiltaan poikkeuksellisen kuuma. Heinäkuun ensimmäisen viikon jälkeen alkoi lähes tauoton yli kahden viikon hellekausi, jolloin maksimi päivälämpötila ylitti $25^{\circ} \mathrm{C}$. Riittävästä laidunalasta johtuen tämä ei vaikuttanut laidunkierron onnistumiseen ja lehmille pystyttiin koko ajan tarjoamaan suunniteltu päivittäinen laidunmäärä. Myös kesä 2005 oli kasvuoloiltaan poikkeava. Laidunkauden alku oli viileä (1.6-10.6 keskim. päivämaksimi alle $\left.15^{\circ} \mathrm{C}\right)$ ja tämän jakson jälkeinen lämmin ja riittävän kostea sää aiheutti voimakkaan nurmenkasvun. Nurmen kehitysrytmi oli niin nopea, että hoitoteknisesti laidunnurmen korsiintumista ja laadun heikkenemistä ei käytännössä voitu estää. Puhdistusniittojen avulla tilanne korjaantui heinäkuun alusta alkaen. Molempina vuosina tutkimuksessa käytetyn säilörehun laatu vaihtui kesken koekauden (taulukko 1). Peräkkäisistä korjuupäivistä huolimatta (20-21.6.2004) vierekkäisiltä lohkoilta korjatut rehuerät (koevuosi 2005) olivat sulavuudeltaan yllättävän erilaista (kesäkuu vs heinä + elokuu). Samoin yölaidunvertailussa (koevuosi 2003) heinä- ja elokuussa syötetyn rehuerän D-arvo oli korjuuajankohtaan (14.6.2002) verrattuna alhainen. Tämän tekstin kirjoitushetkellä kesän 2005 rehulaboratorioanalyysit eivät olleet vielä valmistuneet, joten taulukossa 1 on ilmoitettu käytettävissä olleet Valion NIR analyysiin perustuvat säilörehuanalyysit.

Taulukko 1. Tutkimuksessa käytettyjen kevätsadon säilörehujen NIR -analyysit.

\begin{tabular}{lccc}
\hline & kesäkuu & heinäkuu & elokuu \\
\cline { 2 - 4 } 2003 & & & \\
D-arvo & 68 & 64 & 65 \\
NDF, g/kgka & 550 & 580 & 580 \\
Raakavalkuainen, g/kgka & 186 & 157 & 162 \\
Syönti-indeksi & 99 & 90 & 93 \\
& & & \\
2005 & & & \\
D-arvo & 70 & 66 & 66 \\
NDF, g/kgka & 550 & 560 & 560 \\
Raakavalkuainen, g/kgka & 148 & 179 & 167 \\
Syönti-indeksi & 103 & 96 & 98 \\
& & & \\
\hline
\end{tabular}

Laidunryhmän maitotuotos oli molempina koevuosina sisäryhmää suurempi (kuva 1). Tämä on vastoin toisinaan esitettyä olettamusta, että laiduntaminen pienentää lehmien maitomäärää. Meijereiden tilastojen mukaan karjojen kesäkauden vastaanotettu maitomäärä on pienempi mitä poikimajakauman perusteella pitäisi saada (katso Brofeldt 2005). Tämä tutkimus osoittaa, että tuotosten aleneminen ei johdu sinällään laidunrehusta vaan ilmeisesti puutteista laidunkierron toteuttamisessa. Meijereiden tilastojen mukaan vastaanotettu maitomäärä tyypillisesti pienenee hellekauden aikana, minkä vuoksi kuumuutta on pidetty yhtenä tekijänä kesäkauden maitomäärien notkahduksessa. Kesän 2003 aikana oli lähes kolme viikkoa kestänyt hellekausi. Tutkimuksessa käytetyillä lehmillä tämä helle ei kuitenkaan aiheuttanut mitään romahdusta maitotuotoksessa, joten helle ei tarkoita välttämätöntä maitotuotoksen pudotusta (Sairanen 2004). Samoin vuonna 2005 helleviikolla (heinäkuun toinen viikko) päivälaiduntajien tuotokset (kuva 1) itse asiassa nousivat. Ilmeisesti useilla käytännön maatiloilla kuivan kauden aikana lehmien lisäruokintaa ei nosteta tarpeeksi nurmen kasvun heikentyessä ja lehmien tuotanto kärsii yksinkertaisesti rehun puutteesta, tai sitten puutteista vedensaannissa. Suomen olosuhteissa lämpöstressi ei sinällään ole lehmille suuri ongelma, koska hellekauden aikana ilman suhteellinen kosteus on meillä alhainen. Lehmillä lämpöstressiä alkaa ilmaantua yli $25^{\circ} \mathrm{C}$ lämpötiloissa kun ilman suhteellinen kosteus on riittävän korkea (Kadzere 2002). 
Kuva 1. Säilörehu- ja laidunryhmien välinen maitotuotosero laidunkausina 2003 ja 2005.


Yölaidunryhmän (vuosi 2003) maitotuotos oli keskimäärin 3,9 kiloa sisäryhmää suurempi (taulukko 2). Ero oli havaittavissa heti laidunkauden alussa huolimatta erittäin hyvälaatuisesta säilörehusta. Sulavuudeltaan heikomman säilörehun tultua ruokintaan heinäkuun alussa ryhmien välinen ero kasvoi huomattavasti alkukesää suuremmaksi. Käytännön ruokintatilanteessa eroa olisi osittain voitu kuroa pienemmäksi lisäämällä säilörehuryhmän väkirehuannosta huomattavasti suuremmaksi kuin kokeessa käytetty $9 \mathrm{~kg} / \mathrm{pv}$.

Kesäkuussa 2005 nurmen kasvu oli poikkeuksellisen voimakas ja tämän seurauksena laitumet pääsivät väkisin vanhenemaan lähes säilörehuasteelle saakka. Tämä näkyy päivälaiduntajien kuvassa ryhmien välisen eron puuttumisena kesäkuun puolivälistä heinäkuun alkuun. Heinäkuun alussa laidunten laatu parantui ja samalla syötetyn säilörehun D-arvo aleni 70:stä keskimäärin tasolle 66. Vastaavana aikana maitotuotosero lisääntyi keskimäärin 2 kilon suuruiseksi. Laskennalliseen syöntiin perustuva (energianormit, MTT 2004) päivälaidunryhmän dieetin karkearehuosuuden D-arvo oli hieman yli yhden D-arvoyksikön verran sisäryhmää suurempi, joten pelkkä rehun laatu ei pysty selittämään havaittua maitotuotoseroa.

Kesän 2003 kokeessa oli mukana määräalaniittoon perustuva laidunrehun syönninmääritys. Kokonaissyönti oli laidunryhmällä lehmää kohti keskimäärin 1,7 kgka päivässä suurempi säilörehuryhmään verrattuna, mikä energianormien mukaan vastaisi 3,7 maitokilon tuotosvaikutusta. Todellisuudessa syönnin lisäyksestä saatava energia ei ohjaudu kokonaisuudessaan maitoon mutta ilmeisesti suurin osa havaitusta 3,9 maitokilon tuotoserosta johtuu syönnin lisääntymisestä ja pienempi osa dieetin karkearehuosuuden sulavuuden noususta laidunrehun korvatessa säilörehua. Laiduntamisen maitotuotosta nostava vaikutus oli päivälaidunryhmällä huomattavasti pienempi verrattuna yölaidunryhmään. Tämä on mitä ilmeisimmin seurausta päivälaiduntajien lyhyemmästä laidunajasta, 6 tuntia, verrattuna yökauden 12 tuntiin. Lyhyt laidunaika pienentää syödyn laidunrehun määrää ja samalla hyvin sulavan rehun edut vähenevät.

Taulukko 2. Laiduntamisen vaikutus maitotuotokseen.

\begin{tabular}{clrcccc}
\hline & & Sisäryhmä & $\begin{array}{l}\text { Osa-aika } \\
\text { laidun }\end{array}$ & sem & $\begin{array}{l}\text { P } \\
\text { käsittely }\end{array}$ & $\begin{array}{c}\text { Jakso } \\
\text { käsittely }\end{array}$ \\
\hline koevuosi & kg/vrk & & & & & \\
2003 & Maito & 27,5 & 31,4 & 0,5 & $* * *$ & $* * *$ \\
2003 & EKM & 27,5 & 30,6 & 0,45 & $* * *$ & $*$ \\
2005 & Maito & 27,0 & 28,5 & 0,7 & 0 & $* *$ \\
2005 & EKM & 26,7 & 27,5 & 0,51 & & $* *$ \\
\hline
\end{tabular}

1) käsittely = säilörehu/osa-aikalaidunryhmät, jakso = kesän ajankohta

Ulkomaisen tutkimuksen mukaan (Orr ym. 2001) lehmien maitotuotos oli noin kilon suurempi silloin kun lehmät on päästetty laitumelle illalla verrattuna aamulla tapahtuneeseen lohkonvaihtoon. Vertailussa laidunaika pysyi kummassakin tapauksessa samana. Iltalohkonvaihdon paremmuutta on selitetty 
iltaruohon korkealla sokeripitoisuudella ja hyvällä maittavuudella. Käyttäytymisseurantojen perusteella lehmien aktiivisin syöntiaika on juuri illalla laitumelle laskun jälkeen. Ilmeisesti osa kesän 2003 yölaidunryhmän korkeasta maitotuotoksesta voi johtua iltaruohon maittavuudesta ja tämän seurauksena lehmien lisääntyneestä syöntiaktiivisuudesta. Toisaalta on myös mahdollista, että lehmät ovat luonnostaan ilta-aktiivisia laiduntajia.

Vaikka helle ei Suomessa ole huomattava tuotantoa rajoittava olosuhdetekijä, on yölaiduntamisesta lehmille etua. Lehmät alentavat syöntiään lämpötilan noustessa yli $25^{\circ} \mathrm{C}$ ja vaikka tuotosromahduksesta ei vielä voida puhua, on kuumuus epämukavuutta aiheuttava tekijä ja samalla haitta lehmien hyvinvoinnille. Hellekaudella lehmät läähättivät laitumelta tullessaan ja osa lehmistä laittautui heti sisälle tultuaan parteen makuulle. Ilmeisesti viileä betoni jäähdytti lehmiä. Yökaudella laidunnettaessa lehmät voivat nauttia viileydestä ja samalla tyhjä navetta jäähtyy seuraavaa päivää varten. Kesän 2003 aikana mitattiin laiduntamisen etuja lehmien hyvinvoinnille terveystietojen, veren stressihormonipitoisuuden ja käyttäytymisseurannan avulla. Tutkimuksessa ei voitu todistaa laiduntamisen hyvinvointietuja mutta laiduntamisen mahdollistamaa lajityypillistä käyttäytymistä ei voida kiistää. Sisäryhmän mitattavissa oleva stressittömyys ja terveysongelmien puute kertovat sen, että tutkimuksen mukaisesti hoidetut lehmät eivät parressa pidettyinä voi huonosti. Käytetty tutkimusasetelma ei kuitenkaan pysty mittaamaan sitä, kokevatko lehmät laidun- ja sisäruokintaolosuhteet samanarvoisiksi.

Päivälaidunkokeen yhteydessä tutkittiin myös valkuaislisän merkitystä laidunruokinnassa. Yhtä viljaa korvaavaa rypsikiloa kohti säilörehuryhmän tuotosvaste oli sisäruokintakaudelle tyypillinen 0,9 $\mathrm{kg}$ maitoa/rypsikilo (Huhtanen 1998). Osa-aikalaidunryhmällä vaste oli pienempi; 0,5 kg maitoa/rypsikilo (valkuainen*laidun yhdysvaikutus $\mathrm{P}<0,07$ ). Tulos on johdonmukainen aikaisempien kokoaikalaitumen valkuaislisäruokintakokeiden kanssa. Luomulaitumilla lisärypsistä on saatu hyviä tuotosvasteita, mutta tavanomaisessa tuotannossa vasteet ovat olleet heikompia tai maitotuotosvastetta lisävalkuaiselle ei ole saatu ollenkaan. Uusi-Seelantilaisten ohjeisuksen mukaan alle 30 kiloa tuottavat lehmät eivät tarvitse ollenkaan lisävalkuaista (Kolver 2000). Laidunrehu on hyvä energianlähde pötsin mikrobivalkuaistuotannolle minkä seurauksena laitumen OIV -arvo on korkea. Laidunrehun osuuden lisääminen dieetissä vähentää täten lisävalkuaisen tarvetta. Rehutaulukoissa nurmiheinien aikaisen korjuun mukainen $96 \mathrm{~g}$ OIV /kgka hyvälle laidunrehulle varmaan pitää paikkaansa.

Osa-aikalaidun on järkevä tapa toteuttaa 1.7.2006 voimaantuleva lypsylehmien ja maidontuotantoa varten kasvatettavien hiehojen jaloitteluvelvollisuus. Sopivan laidunalan puute on usein ollut perusteena luopua kokonaan laiduntamisesta, etenkin kun navettainvestoinnin jälkeen karjakoko on lisääntynyt. Tämän tutkimuksen mukainen päivälaidunryhmän 4 ry/pv laidunmäärä (energianormeihin perustuva syönti) saadaan alkukesällä 0,09 ha lehmäkohtaiselta alalta ja loppukesällä tarvitaan 0.14 hehtaaria lehmää kohti (katso laidunalan laskenta www.mtt.fi/tutkimus/alueellinen tutkimus/tuloksia maaninka.html). Kokeen mukaisesti ruokitussa viidenkymmenen lehmän karjassa päivälaiduntajille riittäisi täten reilu 4 ha navetan läheisyydessä. Tehokkaasti toimivalla laidunkierrolla pienempikin laidunala riittäisi. Esimerkkilaskelmassa on käytetty laitumen lisäkasvun hyväksikäyttöprosenttina $50 \%$, mutta hyvin suunnitellulla osaaikalaitumella on mahdollista hyödyntää jopa 60-70 \% nurmen lisäkasvusta.

Käytännössä osa-aikalaidun voidaan toteuttaa tästä tutkimuksesta poiketen myös muilla tavoin. Suuren karjan rehuhuoltokokonaisuutta ajatellen laiduntamisen voisi toteuttaa esimerkiksi siten, että ensimmäinen sato korjataan kokonaan säilörehuksi ja lehmät lasketaan laiduntamaan vasta säilörehun odelmalle. Heinäkuussa nurmen kasvu on vielä hyvä ja lehmät voivat olla laitumella kokoaikaisesti. Nurmen kasvun heikentyessä lehmät siirtyvät aluksi yölaiduntajiksi ja loppusyksyllä päivälaiduntajiksi öiden muuttuessa kylmemmiksi. Päivälaitumen avulla laidunaikaa on hyvin joustava mitoittaa laidunlohkojen kasvun mukaan. Menettelyn avulla tila maksimoi tuotosvaikutukseltaan hyvän ensikorjuun säilörehusadon määrän ja hyödyntää lisäksi osa-aikalaitumen maitotuotosedun. Samalla vältytään kalliilta jaloittelutarhainvestoinnilta. Jaloittelutarhan eduksi täytyy kyllä mainita mahdollisuus talviulkoilutukseen. Laidunrehun rehuarvo maidontuotannossa säilyy hyvänä myös loppukesällä, koska nurmen jälkikasvuaika ei ylitä yhtä kuukautta toisin kuin säilörehun jälkikasvu. 


\section{Johtopäätökset}

Säilörehun korvaaminen laidunrehulla nosti selvästi maitotuotosta. Yölaitumella laidunrehun osuus dieetistä oli suurempi ja vastaavasti myös maitotuotos oli suurempi verrattuna päivälaiduntamiseen. Laitumen edullinen vaikutus johtuu osittain dieetin karkearehuosuuden sulavuuden noususta mutta myös kuiva-aineen syönnin lisäyksellä on suuri merkitys. Osa-aikalaidun vähentää laidunalan tarvetta ja soveltuu etenkin tiloille, joilla on pieni laidunala suhteessa lehmämäärään. Valkuaislisäruokinnasta saatavat heikommat vasteet verrattuna pelkkään säilörehuruokintaan osoittavat laidunrehun hyvän OIV -arvon. Näiden kokeiden perusteella ei voi antaa täsmällisiä ohjeita laidunkauden valkuaisruokinnasta, mutta määrällisesti lisävalkuaisruokintaa on laitumella mahdollista vähentää.

\section{Kirjallisuus}

Brofeldt, E. 2005. Tasainen maidontuotanto myös laidunkauden lopulla on koko maitoketjun etu. Maito ja Me 5: 5 .

Huhtanen, P. 1998. Supply of nutrients and productive responses in dairy cows given diets based on restrictively fermented silage. Agric. Food Sci. Finl. 7:219-250.

Kadzere, C. 2002. Heat stress in lactating dairy cows: a review. Livest. Prod. Sci. 77:59-91.

Kolver, E. 2000. Nutrition guidelines for the high producing dairy cow. Proceedings of the Ruakura Dairy Farmers' Conference, 52: 17-28. http://www.dexcel.co.nz/data/usr/kolver.pdf

MTT 2004. Rehutaulukot ja ruokintasuositukset. [verkkojulkaisu]. Maa- ja elintarviketalouden tutkimuskeskus. Julkaistu 30.6.2004, saatavilla http://www.agronet.fi/rehutaulukot/.

Orr, R., Rutter, S., Penning, P., Rook, A. 2001. Matching grass supply to grazing patterns for dairy cows. Grass and Forage Sci. 56:352-361.

Sairanen, A. 2004. Lehmä viihtyy viileässä. KM VET 4: 8-9.

Sairanen, A., Hakosalo, J., Virkajärvi, P., Mononen, J., Kauppinen, R., Khalili, H., Ahola, L., Lindeberg, H. 2004. Osittaislaidunnuksen vaikutus lehmien tuotokseen ja hyvinvointiin. In: Toim Anneli Hopponen ja Marketta Rinne. Maataloustieteen Päivät 2004, 12.-13.1.2004 Viikki, Helsinki. Suomen maataloustieteellisen seuran tiedote 19: $4 \mathrm{p}$. 